\title{
ČESKÁ ÚSTAVNOST JAKO HODNOTOVÝ RÁMEC INTEGRACE CIZINCŮ
}

\author{
KATEŘINA ŠIMÁČKOVÁ
}

\section{Abstract: Czech Constitutionality as a Value Framework for the Integration of Foreigners}

The article deals with the topic of constitutional values in relation to the integration of foreigners into the Czech society. The first part refers to the question whether we respect the basic constitutional values (respect for human rights and the rule of law) in regulating the status of foreigners and enquires about the main deficiencies of the legislation as well as legal practice in this area. The next part deals with reflections on the topic whether and how the integration of foreigners could be complicated by the fact that the topic of 'the nation' may form part of the Czech constitutional identity. The third part focuses on the issue of secularism and the arrival of new religions, and the way in which constitutional law can reflect this topic. The key idea of the article is the final claim that if we want to demand respect for our principal constitutional values by foreigners, then it should be us in the first place who respects and upholds these values, also in relation to foreigners.

Keywords: constitutional values; rule of law; constitutional identity; nation; secular state; secularism; integration of foreigners from the perspective of constitutional values

Klíčová slova: ústavní hodnoty; právní stát; ústavní identita; národ; sekulární stát; sekularismus; integrace cizinců z hlediska ústavních hodnot

DOI: $10.14712 / 23366478.2018 .2$

\section{MY A NAŠE HODNOTY VE VZTAHU K PŘICHÁZEJÍCÍM CIZINCŮM}

Cizinci přicházejí do našich zemí, členských států Evropské unie, protože tu máme na rozdíl od jejich zemí mír a bezpečí, prosperitu a svobodu spojenou s úctou k lidským právům každého jednotlivce. Přicházejí z válečných zón či bezpečnostně nejistých regionů, za lépe placenou prací či za př́ibuznými, kteří tu už žijí. Někteří mají i politické či ryze osobní důvody (tř̌eba zakázanou sexuální orientaci, diskriminaci svého genderu nebo svého náboženství). ${ }^{1}$ Přicházejí tedy ze srovnatelných důvodů, proč jednotlivci emigrovali v době komunismu od nás. Ti tak činili bud’ z obav o svůj život či bezpečí, pokud se nějak znelíbili režimu, ale také za svobodnějším životem, přičemž svobodou mysleli hlavně možnost cestovat bez omezení nebo nebýt hodnocen dle tříd-

1 Srov. např. výzkum německého Institutu pro výzkum pracovního trhu (http://www.iab.de/en/daten /iab-brain-drain-data.aspx\#General information) nebo analýzy Člověka $\mathrm{v}$ tísni (https://www .clovekvtisni.cz/co-delame/migrace-v-souvislostech) či Amnesty International (https://www .amnesty.cz/migrace/migrace-myty-a-fakta), vycházející ze statistik UNHCR (http://www.unhcr .org/figures-at-a-glance.html). 
ního původu svých rodičů; ale též kvalitnější konzum, lepší platy a možnost vykonávat vytoužené povolání či podnikat.

Cílovou zemí se na rozdíl od minulosti stáváme proto, že jsme mírovou, bezpečnou zemí, máme ekonomickou prosperitu a relativní bohatství a jsme demokratickou zemí, dodržující principy vlády práva a respektující lidská práva. Tedy ty výdobytky naší civilizace, které jsou od příchozích cizinců nejvíce žádané, jsou současně i hodnotami, které oceňujeme i my a které nás též vedou k naší reakci na př́chod cizinců. Velké imigrační vlny nám připadají nebezpečné, protože by mohly destabilizovat naši bezpečnou společnost, o svou prosperitu se nechceme dělit, nicméně tušíme, že ji pomáhají spoluvytvářet i levní zaměstnanci z ciziny. Lidé z nedemokratických režimů či z jiných náboženských a civilizačních oblastí nám připadají pro své zvyky, tradice a hodnoty nebezpeční i s ohledem na ochranu naší otevřené sekularizované společnosti.

Chceme-li se zamyslet nad hodnotovým rámcem integrace cizinců do naší společnosti z pohledu našich ústavních hodnot, nezbývá než nejprve definovat, jaké jsou naše ústavní hodnoty vis à vis přicházejícím cizincům, tedy i při naší reakci na nedávnou migrační vlnu. Ta vyvolala zejména v zemích střední Evropy (tzv. Visegradské čtyřky) politickou odezvu spíše nepřátelskou jak vůči přicházejícím cizincům, tak i příslušné evropské regulaci. Před tím, než se zamyslíme nad tím, se kterými ústavními hodnotami se mají k nám přicházející cizinci seznámit či si je zvnitřnit, je však třeba, abychom se ujistili, zda a jaké takové ústavní hodnoty máme a ctíme my. I mezi občany státu jsou přece lidé, kteří východiska našeho ústavního pořádku mohou znát třeba i zpaměti, ale sami je považují spíše jen za ornament či frázi, nikoli za opravdový obsah naší státnosti. I tento pohled vede $\mathrm{k}$ jisté pochybnosti, zda pro integraci do společnosti stačí znalost ústavního systému a jeho hodnot, vždyt' přece mnohem důležitější je reálně žít podle nich, byt' i bez schopnosti je vyjmenovat. $Z$ tohoto pohledu lze totiž rozlišit znalost, akceptaci a zvnitřnění hodnot projevené v žité praxi.

Náš ústavní systém je postaven na principech pluralitní otevřené společnosti, ${ }^{2}$ vycházející z respektu ke každé lidské bytosti a její svobodě, důstojnosti a rovnosti s ostatními. A to i v př́padě, že se jedná o cizince. ${ }^{3}$ Právě téma vstřícnosti a respektu k právům cizinců přitom tvoří možná jeden z nejzásadnějších hodnotových rozporů uvnitř naší české i celé evropské společnosti. Velmi zásadně se to třeba demonstruje i na judikatuře českých vysokých soudů, např́íklad aktuálně lze upozornit na dva silné názorové proudy v plénu Ústavního soudu k návrhu na zrušení rozsahu veřejného zdravotního pojištění pro absenci př́istupu $\mathrm{k}$ němu u těhotných žen a novorozenců, majících v ČR dlouhodobý pobyt (šlo o finanční dostupnost a zátěž spojenou s porodem a poporodní

2 Dlužno podotknout, že mi jeden z recenzentů tohoto textu vytkl, že český ústavní systém je sice založen na pluralitním politickém systému a svobodě projevu, nicméně nelze prý tvrdit, že otevřená pluralitní společnost je náležitostí českého ústavního pořádku; jedná se prý jen o koncept filozofický, formulovaný Karlem Popperem. Jsem však přsesvědčena, že bez naplnění podmínky otevřené pluralitní společnosti je fungování demokratického právního systému, jak je zakotven v naší ústavě a vykládán Ústavním soudem, nemožné.

3 K tomu více v článku ŠIMÁČKOVÁ, K.: Cizinci v Čechách aneb komu zvoní hrana. In JíLEK, D. - POŘIZEK, P.: Vizová politika a praxe ČR v kontextu Evropské unie. Quo vadis visum? Praha, 2010, s. 13 a násl. nebo v projevu ŠIMÁČ́KOVÁ, K.: Zamyšleni nad uprchlickou krizi a našimi hodnotami, předneseném 12. 11. 2015 na konferenci Uprchlická krize a Česká republika na Právnické fakultě Univerzity Karlovy v Praze a dostupném na www.migraceonline.cz. 
péčí o novorozené děti). Ten názor, který s osmi hlasy zvítězil, zdůraznil, že nositelem ústavního práva na bezplatnou zdravotní péči na základě veřejného pojištění je pouze občan České republiky, zatímco nositelem práva na ochranu zdraví je každý. Podle zmíněné osmičlenné většiny není úkolem Ústavního soudu zahajovat či vstupovat do veskrze politické diskuse na téma vhodnosti stávajícího osobního rozsahu zdravotního pojištění. Naopak přehlasovaná sedmičlenná menšina ve svém společném disentu poukázala na to, že pro novorozence a jejich matky - cizinky, které mají v ČR dlouhodobý pobyt, a tedy tu pracovaly a solidárně do veřejného pojištovacího systému dříve přispívaly a jejichž manželé zpravidla v ČR stále pracují, mají dle čl. 32 Listiny základních práv a svobod ústavně zaručené právo na zvláštní péči o těhotné ženy a děti bez ohledu na jejich občanství, u novorozenců pak je třeba na celou situaci uplatnit i závazek zvláštních záruk stran realizace jejich práva na ochranu zdraví dle čl. 24 odst. 1 Úmluvy o právech dítěte. ${ }^{4}$

Ústavní soud pak v době vrcholící politické kampaně v souvislosti s uprchlickou krizí čelil vlně kritiky, když vyhlásil nález, jímž shledal nedostatečné naplnění povinnosti efektivního vyšetřování při správním vyhoštění cizince, který byl vystaven nelidskému a ponižujícímu zacházení ze strany cizinecké policie. ${ }^{5}$ I přes hrozící migrační krizi však přece nelze opustit bezvýhradný ústavní imperativ, že žádného člověka nemáme nikdy vnímat jako problém, ale jako lidskou bytost nadanou důstojností a přirozenými právy. Jen proto, že se někdo narodil a vyrůstal $v$ jiné zemi, není vyloučen $\mathrm{z}$ této ochrany před nespravedlností, zabitím, nucenými pracemi či nelidským a ponižujícím zacházením. Policii př́sluší vykonat pravomocně uložené správní vyhoštění i proti vůli cizince; musí se tak však dít způsobem, který plně respektuje důstojnost a práva vyhoštovaných. Cizinec i za těchto okolností zůstává člověkem, který má právo na lidské a důstojné zacházení. Nejen samotné zbavení osobní svobody, ale i celkové okolnosti realizace vyhoštění musí být proto humánní a prokazovat dostatečný respekt k člověku.

Ve výuce ústavního či mezinárodního práva $\mathrm{k}$ tématu lidských práv bývá poukazováno na to, že kvalita, vyspělost a humanita každé společnosti se pozná podle způsobu, jakým zachází s těmi nejzranitelnějšími, s těmi, kdo se z jakýchkoli důvodů ocitli na jejím okraji, tedy například s lidmi bez domova, ve věznicích, v psychiatrických léčebnách nebo $\mathrm{v}$ cizineckých detenčních zařízeních. Jen proto, že se někdo narodil a vyrůstal v jiné zemi, jej nevylučuje z lidskoprávní ochrany v zemi, na jejímž území se nachází. I z české ústavní úpravy přece vyplývá, že každá lidská bytost, at’ už je, či není „našincem“, musí být bez výjimek chráněna před nelidským a ponižujícím zacházením.

V českém právu to pak nejsou jen mezinárodní a evropské závazky, ale též ústavní hodnoty úcty $\mathrm{k}$ lidským právi̊m, které stát zavazují poskytnout cizincům ve skutečné nouzi mezinárodní ochranu, př́padně dočasnou ochranu, a základní lidskoprávní standard.

Respekt k pravidlům při zacházení s cizinci též napomáhá dodržení imperativu nepodkročitelnosti standardů lidskoprávní ochrany i pro občany samotné. Pokud totiž ústavní pořádek zavazuje stát dodržovat základní pravidla chránící každého jednotlivce,

4 Nález Pl. ÚS 2/15 ze dne 3. 5. 2017, č. 185/2017 Sb.

5 Nález Ústavního soudu sp. zn. I. ÚS 860/15 ze dne 27. 10. 2015 (N 191/79 SbNU 161). 
pak není na místě v tomto tvrdém jádru práv jakkoli rozlišovat mezi lidmi, což ústavodárce stvrzuje označením, že nositelem těchto práv je „,každý“.

Užitečnost dohlížení na dodržování práv cizinců je založena na tom, že pokud připustíme, aby se stát choval k některým lidským bytostem na svém území svévolně, bez kontroly a bez respektu, tak si na to zvykne a brzy to může začít aplikovat i na nás ostatní. ${ }^{6}$ Naše ponižující či neférové chování vůči cizinci se může „,našinci“ vrátit při dalším jeho setkání s tímto cizincem či někým jemu blízkým. Někteří tu mezi námi prostě zůstanou a s těmi, co odejdou, budeme sdílet stejnou planetu, která je díky globalizaci prostě stále menší. Pak se s nimi my nebo naši blízcí můžeme potkat v stejně zranitelné situaci, v jaké se oni potkali s námi.

Úvaha nad hodnotovým základem, na němž spočívá vnitrostátní právní úprava jednání státu vůči cizincům (třeba i nelegálně) pobývajícím na jeho území je nezbytným základem úvahy o tom, s jakými hodnotami se mají cizinci na našem území ztotožňovat, tedy jakému hodnotovému řádu se vlastně mají přizpůsobit a integrovat se do něj. Jak můžeme po cizincích chtít, aby sdíleli naše ústavní hodnoty, když se jich nedržíme v jednání s nimi? Jednou z nejdůležitějších sebedefinujících charakteristik našeho státu je, že je právním státem, tedy, že je založen na vládě práva a pravidel, přičemž jedna ze základních zásad a podmínek fungování vlády práva a dodržování práva jednotlivci je jeho srozumitelnost a dostupnost, jednoznačnost jeho účelů a jeho vymahatelnost. V nedávné době bylo Ústavním soudem i Veřejnou ochránkyní práv identifikováno, ${ }^{7}$ že jsou cizincům v zajišt'ovací detenci doručena rozhodnutí o správním vyhoštění, ale v odvolací lhưtě jim není zajištěna právní pomoc, tudíž nemají reálnou možnost pochopit svou právní situaci a podat si odvolání. Rozhodnutí nerozumějí, a proto nepoznají, jaké zákonné podmínky byly v jejich prrípadě prrípadně porušeny. Přesto se rozhodnutí stane pravomocným a oni jsou ze země vyhoštěni. A zákonodárce v poslední novele cizineckého zákona dokonce vyloučil možnost soudní obrany proti zajištění pro účely vyhoštění, pokud již k vyhoštění došlo, ${ }^{8}$ přičemž reakce Nejvyššího správního soudu na tuto situaci je rozporuplná. 9

Navíc lze právě o předpisech cizineckého práva, zejména o zákoně o pobytu cizinců a zákoně o azylu, ${ }^{10}$ konstatovat, že jsou mimořádně nekonzistentní, nesrozumitelné, jejich části už byly opakovaně Ústavním soudem shledány jako protiústavní (např. pro

${ }^{6}$ K tomu více ŠIMÁČKOVÁ, K.: Fiktivní, nebo reálná ústava. In BOBEK, M. - MOLEK, P. - ŠIMÍČEK, V. (eds.): Komunistické právo v Československu. Kapitoly z dějin bezpráví. Brno, 2009, s. 123 a násl. Dostupné z: www.komunistickepravo.cz.

7 Popsáno v nálezu Ústavního soudu sp. zn. I. ÚS 630/16 ze dne 29. 11. 2016.

8 § 169r odst. 1 písm. i) a ustanovení § 172 odst. 6 zákona č. 326/1999 Sb., o pobytu cizinců na území České republiky, ve znění pozdějších předpisů, a ustanovení § 46a odst. 9 a § 73 odst. 8 zák. č. 325/1999 Sb., o azylu, ve znění pozdějších předpisů.

9 Jeden ze senátů odsouhlasil postup správních orgánů podle této úpravy, jiný senát položil předběžnou otázku SD EU a další úpravu neaplikují pro rozpor s unijním právem, a to vše v situaci, kdy se kvalifikovaný navrhovatel (skupina senátorů) obrátil s návrhem na zrušení právní úpravy na Ústavní soud (ř́zení je vedeno pod sp. zn. Pl. ÚS 41/17). Situace je podrobněji popsána v článku HOMOLKOVÁ, B. - KUNCOVÁ, L.: Omezení soudního přezkumu zajištění cizincủ. Právní rozhledy, 2018, č. 4, s. 134 a násl.

10 Zákony č. 325/1999 Sb. a č. 326/1999 Sb. s velkým množstvím novel a bez dostatečného propojení. 
vyloučení soudního přezkumu ${ }^{11}$ či př́iliš krátké lhůty pro podání žaloby ${ }^{12}$ ), část pravidel není upravena $\mathrm{v}$ zákoně, ale prímo plyne z evropského práva. Rovněž správní praxe při aplikaci cizineckých předpisů vykazuje řadu nedostatků - např́klad arbitrárně vymáhané místo výkonu práce u pracovních víz či podivná praxe call center při nabírání žádostí o pracovní víza. Nelze pominout ani to, že český stát jednoznačně nedává najevo, zda a o jaké cizince stojíme či zda jsme zcela uzavření a žádnou cizineckou pracovní sílu si nepřejeme. Na osoby z třetích zemí mimo EU, které v naší zemi pracují na základě tzv. dlouhodobých víz, české zákony žádné integrační požadavky nemají. Ty se objevují až v př́ipadě žádosti o trvalý pobyt či občanství ${ }^{13}$ Pro udělení trvalého pobytu je vyžadována znalost českého jazyka. ${ }^{14}$ Požadavek integrace se explicitně objevuje v zákoně až v souvislosti s nabýváním státního občanství. Občanství pak je možno udělit jen, pokud je žadatel integrován do společnosti v České republice z hlediska rodinného, pracovního, nebo sociálního, má znalost českého jazyka a základní znalost ústavního systému ČR a orientaci v kulturně-společenských, zeměpisných a historických reáliích ČR. ${ }^{15}$ Zajišstování integrace žadatelů o azyl či jinou formu mezinárodní ochrany je zákonodárcem formulováno jako povinnost státu jednoznačně jen ve vztahu k žadatelům, spadajícím pod povinnou školní docházku. ${ }^{16}$

\section{ÚSTAVNÍ IDENTITA A NÁROD}

V poslední době zaznívá v politické a kupodivu i odborné debatě v České republice námět, zda by česká Ústava neměla obsahovat odkaz na národ jako hodnotu, která spoludefinuje naši ústavnost. ${ }^{17}$ Vlastenectví a odpovědné občanství se ale nedá vytvořit či vynutit ukotvením v právu a založit ústavní řád na národním principu může být dokonce nebezpečné.

Francouzi už od dob francouzské revoluce vnímají jako východisko svého ústavního pořádku heslo „svoboda, rovnost, bratrstvi““ všech lidí. Američané vyjadřují základ své ústavní identity tak, že si Ústavu sobě dal lid Spojených států za účelem vytvoření jednoty, nastolení spravedlnosti, zachování vnitřní i vnější bezpečnosti, růstu všeobecného blahobytu a zabezpečení svobody pro sebe i své potomky. Nedávno se k ústavní identitě

11 Nálezem sp. zn. Pl. ÚS 26/07 ze dne 9. 12. 2008 (N 218/51 SbNU 709; 47/2009 Sb.) Ústavní soud zrušil vyloučení soudního přezkumu rozhodnutí o správním vyhoštění cizince - tehdejší § 171 odst. 1 písm. c) zákona o pobytu cizinců.

12 U zákona o azylu nálezem sp. zn. Pl. ÚS 41/10 ze dne 17. 9. 2013, publikovaným pod č. 466/2013 Sb. a nálezem sp. zn. Pl. ÚS 17/09 ze dne 1. 12. 2009, publikovaným pod č. 9/2010 Sb.

13 Projevování snahy o integraci může v některých př́ípadech pomoci proti správnímu vyhoštění - u zletilců, kteří byli v době své nezletilosti svěřeni do české náhradní výchovy - $\$ 122$ odst. 5 a 6 zákona o pobytu cizinců.

$14 \S 70$ zákona č. 326/1999 Sb. (jen na půdorysu požadavku potvrzení znalosti jazyka formou předložení př́íslušného dokladu).

15 Srov. § 13 zákona č. 186/2013 Sb.

$16 \S 80$ zákona č. 325/1999 Sb.

17 Srov. např́klad opakovaná vystoupení prof. Aleše Gerlocha k této otázce; poprvé na podzim 2016 v rámci akce Pražský právnický podzim (https://www.pravniprostor.cz/clanky/ustavni-pravo/pripravovane-ustavni -zmeny-prof-gerloch-a-judr-fiala), př́ípadně jeho vyjádření v médiích (https://faei.cz/rozhovor-nebyt -ceskeho-naroda-nebylo-by-ani-ceskeho-statu-rika-ustavni-pravnik-ales-gerloch/). 
vyslovil i německý Ústavní soud, který ji našel zejména v tématu lidské důstojnosti. ${ }^{18}$ Podle prvního článku české ústavy je naše ústavní identita založena na třech základních pilírích, kterými jsou demokracie, vláda práva a úcta k právům a svobodě jednotlivce. Proč však tedy v nedávné době někteří čeští právníci nadnesli úvahu, zda nedoplnit hodnotu národa mezi východiska české ústavnosti či projev ústavní identity? ${ }^{19}$ Působí to, jakoby se tato myšlenka objevila v souvislosti s pocitem nedostatku společenské odpovědnosti, sounáležitosti či národního sebevědomí. To je ovšem něco, co žádný zákon ani ústava nezajistí a ani zajistit nemůže. Ústava však garantuje rovnost lidí a lidskou svobodu a jen ty otevírají pole pro uplatnění odpovědnosti i sounáležitosti ve státě žijícího společenství.

Před vznikem našeho moderního státu na konci devatenáctého století se národním tématem zabýval Tomáš Garrigue Masaryk. Hned v rámci první z předmluv k jeho zásadní knize Česká otázka je zdůrazněno, že národní instinkt je sice drahocenná mocenská politická síla, avšak že každý instinkt by měl být korigován rozumem, nebot' naše emoce a probuzené instinkty by mohly sloužit takovým cílům, které si třeba ani neuvědomujeme. ${ }^{20}$ Pro Masaryka je česká otázka otázkou po osudech člověčenstva, otázkou svědomí. Vlastenectví neznamená dělení lidí na dvě skupiny - našince a cizince - a následné porozumění jen pro ty našince. ${ }^{21}$ Upozorňuje, že nemá ,ppotřeby snižovat národy jiné, aby můj tím vynikal."22 Součástí masarykovského vlastenectví je překročení vlastních limitů - viz pěkné povzbuzení každého Čecha, ,aby povznesl svůj zrak nad ouzké meze své otčiny, a nepřestávaje býti vlastencem věrným, aby spolu stal se světaobčanem bedlivým a opatrným. “23 Masarykova výzva „,troufejme si konečně sami být většími - nejsme tak malí, jak naši vlastenečtí fňukalové nám, a tedy i jiným, namlouvají“ 24 by se možná dala pěkně přetavit v nový český postoj k účasti v evropské integraci a společné evropské cizinecké politice. ${ }^{25}$

\section{INTEGRACE V DOBĚ PříCHODU NOVÝCH NÁBOŽENSTVÍ}

V poměrně homogenní a kulturně a národnostně uzavřené společnosti, jíž je společnost česká, se jako velká hrozba jeví islamizace Evropy, ${ }^{26}$ ačkoli s muslimy

18 Nález Spolkového Ústavního soudu BVerfG, Beschl. v. 15. 12. 2015 - 2 BvR 2735/14.

19 Např. předseda Ústavního soudu Pavel Rychetský se vůči tomuto názoru naopak kriticky vymezil (viz např. https://babylonrevue.cz/nic-nez-narod).

20 MASARYK, T. G.: Česká otázka. Naše nynější krize. Praha, 1990, s. 9.

21 Zvolila jsem přístup k české otázce prostřednictvím díla „mladého“ Masaryka; tím nezastírám, že aktuální „národovci“ citovaní v textu mohou mít i jiné inspirace u prvorepublikových autorů - např́klad Karla Kramáře či Edvarda Beneše (viz jeho stručné pojednání Otázka národnostní) a že vyjádřené Masarykovy myšlenky nenalezly v textu prvorepublikové Ústavní listiny žádný explicitní odraz. Ústava z roku 1920 se naopak opírala o sporný koncept československého národa.

22 MASARYK, T. G.: Česká otázka. Naše nynější krize. Praha, 1990, s. 60.

23 Tamtéž, s. 127.

24 Tamtéž, s. 137.

25 K tomu více v ŠIMÁČKOVÁ, K.: Solidarita jako etický př́ikaz. In SVOBODA, J. - PRÁZNÝ, A. (eds.): Česká otázka a dnešní doba. Praha, 2017, s. 381 a násl.

26 Srov. zejména slogany v českém parlamentě aktuálně zastoupené politické strany Svoboda a př́má demokracie (SPD). 
reálně v naší zemi skoro žádné zkušenosti nemáme. V české společnosti je třeba formou kvalitních integračních procesů primárně řešit skutečné zapojení romské menšiny do společného vzdělávání a př́istup $\mathrm{k}$ dostatku pracovních př́iležitostí. Z cizinců v České republice převládají Slováci, s nimiž máme mimořádně podobnou řeč a společnou kulturu i minulost, Vietnamci, na něž jsme si zvykli již v době komunistického režimu, a Ukrajinci, kteří jsou nám též blízcí jazykem, vzhledem i zvyky. Nelze nepřipomenout bezproblémovou absorbci uprchlíků z doby jugoslávské války, a to včetně bosenských muslimů. $^{27}$

Podle judikatury českého Ústavního soudu „Česká republika je založena na principu laického státu. Podle čl. 2 odst. 1 Listiny základních práv a svobod je totiž stát založen na demokratických hodnotách a nesmí se vázat ani na výlučnou ideologii, ani na náboženské vyznání. “Je zřejmé, že Česká republika musí akceptovat a tolerovat náboženský pluralismus, což znamená, že především nesmí diskriminovat či naopak bezdůvodně zvýhodňovat některý z náboženských směrů. Stát musí být oddělen od konkrétních náboženských vyznání. ${ }^{28}$

Naše Listina základních práv a svobod stejně jako ústavy dalších významných demokratických zemí církev a náboženství zařadily mezi instituty jako rodina, politická strana, vzdělání - tedy instituty, instituce, o nichž předpokládáme, že jsou pro fungování naší společnosti z různých důvodů užitečné, a proto je třeba jejich existenci chránit a podporovat. ${ }^{29}$ „Kulturní vývoj Evropy a jemu korespondující vývoj demokratického ústavněprávního myšlení v důsledku laicizace státu neznamená opuštění historické hodnotové tradice, $\mathrm{v}$ tom rámci i tradic náboženských. Znamená ale, že tyto institucionálně již neexistují paralelně vedle, resp. vně demokraticky legitimované veřejné moci, nýbrž uvnitř celého, ústavně vymezeného a garantovaného systému hodnot.“30

Gerhard Robbers, editor knihy Stát a církev v zemích EU, v roce 1995 napsal, že „i přes všechny odlišnosti systémů zde existuje určitý druh konvergence. V některých zemích se postupně odstraňují historicky dochované proticírkevní a antiklerikální afekty a jejich právní důsledky. Náboženským společnostem je vytvářen prostor pro jejich působení a mají zajištěnou stále větší svobodu. Náboženství je hodnoceno jako podstatná součást společenského života a stát také vytváŕí předpoklady pro plnění náboženských potřeb. Často $\mathrm{k}$ tomu dochází širokým pojetím významu základních lidských práv, podle něhož spadá pod péči společnosti rovněž vytváření předpokladů základních práv, která již nejsou vnímána pouze jako obrana proti zásahům státu. A konečně je obecně uznáváno, že náboženské společnosti nesmějí být vylučovány ze systému rozsáhlé podpory společenských aktivit, čímž by docházelo k jejich diskriminaci." "31 Evropský vývoj tedy

27 Srov. opakovaná vyjádření ředitele OPU Martina Rozumka v médiích (např. https://www.tyden.cz/rubriky /domaci/proc-zrovna-ted-cechum-vadi-uprchlici-experti-majiodpoved_354675.html).

28 Pl. ÚS 6/02 ze dne 27. 11. 2002, č. 4/2003 Sb., N 146/28 SbNU 295.

29 Česká Listina základních práv a svobod v čl. 16 odst. 2 garantuje velmi širokou církevní autonomii a preambule zákona o majetkovém vyrovnání s církvemi č. 482/2012 Sb. výslovně uvádí, že existence a působení církví a náboženských společností jsou zákonodárcem pokládány za nezbytný prvek demokratické společnosti.

30 Takto se k problému vyjadřuje konkurenční stanovisko soudců Malenovského a Holländera k odůvodnění rozhodnutí Pl. ÚS 6/02 ze dne 27. 11. 2002, publikovaného pod č. 4/2003 Sb.

31 ROBBERS, G.: Stát a církev v Evropském společenství. In ROBBERS, G. (ed.): Stát a cirkev v zemích EU. Praha, 2002, s. 357 a násl. 
směřuje (či tedy alespoň před dvaceti lety směřoval) ke stále větší podpoře rozmanitosti a činnosti náboženských společenství, nikoli k jejich přísnější reglementaci a k omezování. Uplatní se to ale jen na tradiční křest’anské církve nebo i na islám, a pokud i na něj, tak na jaké jeho směry a projevy?

Jak již bylo uvedeno, Ústavní soud zdůraznil, že Česká republika je laický stát. V návaznosti na tvrzení o laickém státu je třeba zdůraznit, že ateismus a laicismus není totéž. Ateismus není absence ideologií, ale je jednou z ideologií, přičemž v české společnosti se jedná spíše o převládající ideologii, jelikož náboženství jsou u nás vyznávána jen společenskými menšinami. ${ }^{32}$ Pokud by snad pro někoho vyznívalo problematicky definování ateismu jako ideologie, je nesporné, že z hlediska ochrany svobody vyznání je třeba i ateismus chránit jako jedno z vyznání, což se vyjeví zejména v zemích, kde převažuje religiózní obyvatelstvo. ${ }^{33}$

Podle Jiřího Přibáně se v moderní Evropě postupně ustálily dvě odlišné ústavní a politické tradice: Kantův univerzalistický republikanismus, podle kterého se nejprve racionálně zkonstruuje obecný politický model, na jehož základě teprve vznikne svobodná a demokratická společnost, a praktická filosofie Davida Huma, která chápe každý ústavní model jako výsledek reálného politického života a existujících mravů. Každá budoucí evropská ústavnost musí být založena jako zvláštní sít', v níž se budou obě tyto tradice vzájemně doplňovat. ${ }^{34}$ Michal Bobek pak konkrétně k tématu náboženských symbolů vysvětlil, že jsou vlastně dvě krajní možnosti, jak k nim v ideologicky neutrálním demokratickém právním státě přistupovat: bud' veřejný prostor od nich ochránit či vyprázdnit, nebo respektovat jejich pluralitu v něm. ${ }^{35}$

Problematikou místa náboženství v našem životě, právu a politice jsme se nedávno zabývali v souvislosti s restitucemi církevního majetku a předtím ohledně stále neratifikované smlouvy s Apoštolským stolcem či ústavnosti zákona o církvích a náboženských společnostech nejen v České republice, ale v celé Evropě v souvislosti s debatou evropského Konventu o obsahu Smlouvy o Ústavě pro Evropu, zda má být v evropské ústavě zmínka o bohu, a jak přesně má být zmíněn. ${ }^{36}$ A neopomenutelné je v této souvislosti i rozhodnutí Evropského soudu pro lidská práva ve věci Lautsi proti Itálii, podle nějž je povinností finského dítěte přizpůsobit se italským zvykům, spočívajícím v tom, že ve třídě základní školy visí krucifix. Evropský soud pro lidská práva provedl „salto

32 ŠIMÁČKOVÁ, K.: Ideologická neutralita státu a postavení církví v České republice. Revue církevního práva, 2006, č. 3, s. 193-203.

$33 \mathrm{~K}$ tomu srov. napríklad Amicus Curiae Brief on the Compatibility with Human Rights Standards of certain articles of the Law on Primary Education of the Sarajevo Canton of the Federation of Bosnia and Herzegovina adopted by the Venice Commission at its 91st Plenary Session 15-16 June 2012, CDL-AD(2012)013 (dostupné z: www.venice.coe.int).

34 P̌̌IBÁŇ, J.: Disidenti práva. Praha, 2001, s. 176.

35 BOBEK, M.: Náboženské symboly ve veřejném prostoru aneb „Desatero v soudní síni nevyvěsíš, tvář svoji šátkem nezahalíš. Právní fórum, 2005, č. 12, s. 461 a násl.

$36 \mathrm{~K}$ tomu se v českém prostředí vyjádřil např́iklad Ludvík Vaculík 4. 6. 2003 v Senátu Parlamentu ČR při veřejném slyšení Výboru pro evropskou integraci na téma „Evropa jako hodnotové společenství“ takto: „Evropa a křest’anství, to se nedá dát od sebe oddělit. Křest'anství utvořilo Evropu, křest’anství humanizovalo člověka. A Evropa se přizná ke své dobré vůli a úmyslům humanizovat svět, a tím vlastně na zapřenou bude realizovat křest’anství? To se mi nezdá.“ 
vzad z jednomyslnosti malého senátu na drtivý poměr 15:2 k opačnému výsledku“37 a shledal, že ,při rozhodování, zda ponechat krucifixy ve třídách, jednaly státní orgány $\mathrm{v}$ rámci svého prostoru pro uvážení, který je jim ponechán v oblasti respektu k právu rodičů zajišt'ovat výchovu a vzdělání ve shodě s jejich vlastním náboženským a filozofickým přesvědčením. “38

Pavel Molek s Kristýnou Foukalovou ve svém komentáři k případu Lautsi z roku 2011 poměrně jasnovidně připomněli, že „s narůstající migrací bude patrně podobných třecích ploch přibývat: důkazem může být nejen přípustnost či neprrípustnost křest'anských či nekřest’anských symbolů na veřejnosti, ale třeba i otázka, do jaké míry musejí přicházející menšiny respektovat takové hodnoty západních společností, jako je liberální přístup ke svobodě projevu, včetně práva urážet (třeba formou karikování proroka Mohameda). Mají většinové domácí společnosti obrousit hrany své identity tak, aby nemohly ničím zraňovat či urážet přicházející menšiny? Nebo se mají tyto menšiny naopak obalit měkkými polštářky, aby je ony ostré domácí hrany nemohly zranit? Anebo mají potenciálně přicházející menšiny vstupovat jen do takových společností, kde se již nyní vyznávají hodnoty, které by mohly respektovat? Nebo mají evropské společnosti pro jistotu omezit migraci či alespoň kontrolovat u zájemců o usazení, do jaké míry je jejich hodnotový svět kompatibilní s tím, do něhož chtějí vstoupit?“39

Křest’anská náboženství v oblasti lidských práv individualizují člověka, zdůrazňují soucit s utrpením, altruismus. Do úvah věřícího přinášejí sebereflexi jeho činů a myšlenek a nadhled nad potížemi i radostmi života, pomáhají mu v nejtěžších chvílích jeho života. Podle Adama Smithe náboženství posiluje přirozený smysl pro povinnost, nebot' „lidé věřili, že bohové odmění lidskost a milosrdenství a oplatí věrolomnost a bezpráví.“40 „Příroda nás učí doufat a náboženství nás ... opravňuje očekávat, že bezpráví bude potrestáno dokonce i v příším životě ... V každém náboženství ... existoval tartar stejně jako elysium - místo určené pro potrestání hříšníků, stejně jako místo určené pro odměnu spravedlivých." 41

Ve vztahu k přicházejícím cizincům a jejich náboženstvím evropští věřícíi ${ }^{42}$ i celá společnost oscilují mezi dvěma krajními pozicemi. Strachem, aby nebyla celá Evropa muslimy „vyvrácena“ stejně jako Konstantinopol, nebo zdůrazněním humanismu ve vztahu k uprchlíkům před válkami či humanitárními katastrofami a schopnosti křest’anských církví být jakýmisi ,„překladateli“ či mostem mezi evropskou a muslimskou

37 FOUKALOVÁ, K. - MOLEK, P.: Věc Lautsi a další proti Itálii. Kř́̌že v italských školách - velký senát. Přehled rozsudků Evropského soudu pro lidská práva, Praha, 2011, č. 3, s. 189-203.

38 Rozhodnutí Lautsi a dalši proti Itálii, stížnost č. 30814/06, rozsudek velkého senátu ze dne 18. března 2011, bod 76 .

39 FOUKALOVÁ, K. - MOLEK, P.: Věc Lautsi a další proti Itálii. Kříže v italských školách - velký senát. Přehled rozsudků Evropského soudu pro lidská práva, Praha, 2011, č. 3, s. 202.

40 SMITH, A.: Teorie mravních citů. Praha, 2005, s. 166, 172.

41 Tamtéž, s. 99.

42 Křest’anské církve na své pozici morálního arbitra rovněž musí pracovat, aby jí nakonec nezbyla jen majetková a sexuální agenda $\mathrm{v}$ době, kdy severoatlantická civilizace vyzdvihuje neomezený růst, uzavření ve svém bezpečném sobectví, děti v třetím světě umírají hlady a nemocemi, príroda přestává existovat. Nebot' slovy Ivana Štampacha: „Roli duchovní, mravní a kulturní autority nikdo nemá navždy.“ ŠTAMPACH, I. O.: Dům ze skla? Týden, 2000, č. 29, s. 80. 
kulturou. ${ }^{43}$ Projevem tohoto napětí je pak i postoj k různým symbolům muslimského náboženství a kultury, v poslední době pak zejména $\mathrm{k}$ zahalování muslimských žen. ${ }^{44}$

Pro zastánce zvýšení tlaku na nedostatečně integrované muslimy se stává zejména v posledních letech takovou vlajkovou lodí zákaz burek a nikábů ${ }^{45}$ často odůvodňovaný ochranou rovnosti žen a mužǔ, ale mající spíše represivní důvody. Zahalené tváře žen jsou zakazovány proto, že muslimky mají i podle Evropského soudu pro lidská práva povinnost dodržovat minimální požadavky vzájemného soužití ve společnosti, k nimž patř́ i odhalené tváře lidí setkávajících se ve veřejném prostoru. ${ }^{46}$ Př́mou reakcí na teroristické útoky na jihu Francie byl zákaz burkin na nedalekých plážích, opět zaměřený proti ženám, ačkoli mezi teroristickými atentátníky byli jen muži. Následovalo zrušení předpisu Státní radou, ${ }^{47}$ nicméně symbolická reakce proběhla. Právě velká síla symbolů v oblasti legitimace státní moci, ${ }^{48}$ výkonu náboženství a tradic či integrace cizinců je naprosto nepopiratelná a jejich důsledky často nečekané.

\section{ZÁVĚREČNÝ APEL}

Pro výchovu v rodině, stejně jako pro výchovu k odpovědnému občanství je nezbytným a možná nejdůležitějším aspektem osobní příklad. Ani děti, ani dospělé nelze vychovávat efektivněji, než právě vlastním prŕíkladem. Pro evropské státy je pak jedním ze základních hodnotových východisek respektování rovnosti všech lidí a vlády práva, jejíž integrální součástí je i jednoznačnost, transparentnost a vynutitelnost právních pravidel - padni komu padni. Jak již bylo uvedeno, vnitrostátní legislativa i její soudní a exekutivní interpretace ve vztahu k cizincům však tento př́ístup prostě neodráží. Právě v situacích, v nichž regulujeme chování cizinců právem, jim zatím spíše ukazujeme, že jsme někdy připraveni hodnoty vlády práva či rovnosti lidí opustit

43 Srov. článek HALíK, T.: Máme s muslimy stejného Boha? Katolický týdeník, 2015, č. 50, který vyvolal rozsáhlou polemiku, např. ze strany Ctirada V. Pospíśila.

$44 \mathrm{~K}$ tématu $\mathrm{v}$ českém prostředí např́íklad AGHA, P.: Muslimské šátky $\mathrm{v}$ evropském veřejném prostoru. Právnik, 2015, č. 10, s. 785-800; ze zahraničních publikací viz např. BOWEN, J. R.: Why the French Don't Like Headscarves. Islam, the State and Public Space. Princeton, 2008; FOEHR-JANSSENS, Y. NAEF, S. - SCHLAEPFER, A. (eds.): Voile, corps et pudeur. Approches historiques et anthropologiques. Geneve, 2015; ELVER, H.: The Headscarf Controversy. Secularism and Freedom of Religion. Oxford, 2012; KLAUSEN, J.: The Islamic Challenge. Politics and Religion in Western Europe. Oxford, 2005; SCOTT, J. W.: The Politics of the Veil. Princeton, 2007; LAZREG, M.: Questioning the Veil. Open Letters to Muslim Women. Princeton, 2011; McGOLDRICK, D.: Human Rights and Religion. The Islamic Headscarf Debate in Europe. Portland, 2006.

45 Těsně před nabytím účinnosti zákazu burek a nikábů v Rakousku jsem trávila dovolenou v rakouském Zell am See a mohla tam pozorovat různé stupně zahalení arabských žen. Zhruba ve stejnou dobu, kdy zase mohli Egypt’ané pozorovat různé stupně odhalení evropských turistek. Vzpomínám i na to, že před hotelem Grand blankytně modré Ferrari s nápisem Kuvajt parkoval recepční - Bosňák, s nejvyšší pravděpodobností evropský muslim perfektně integrovaný do rakouské společnosti. Oči Arabek byly tak výrazné a jejich děti tak roztomilé, že jsem necítila žádné neprríjemné omezení při osobní komunikaci, ale trochu mne zlobilo, že krmí vodní ptáky, ačkoli bylo všude napsáno, že se to z důvodů ochrany těch ptákủ nesmí.

46 Tak zdůrazňované vivre ensemble / living together v rozsudku Evropského soudu pro lidská práva S. A. S. proti Francii, č. 43835/11 ze dne 11. 4. 2011 výstižně komentovaném v článku SCHEU, H. CH.: Zákaz zahalování žen a náboženská svoboda v Evropě. Jurisprudence, 2014, č. 4, s. 17-23.

47 Srov. rozhodnutí francouzské Státní rady Nos 402742, 402777 ze dne 26. 8. 2016.

48 PŘIBÁŇ, J.: Právní symbolismus. O právu, času a evropské identitě. Praha, 2007. 
a že naše pravidla jsou vykládána či tvořena $v$ jejich neprospěch a umožňují svévoli či ponižování. Jak můžeme očekávat, že v takovém př́padě budou oni naše pravidla považovat za legitimní?

Vyžadovat, aby někdo respektoval naše hodnoty, přece znamená v prvé řadě, že ty hodnoty musíme mít a skutečně je ve svém chování vyjadřovat.

Z nejvýše postavené normy našeho ústavního pořádku plyne, že práva jednotlivce jsou nejvyšší hodnotou a účelem našeho politického a právního systému. ${ }^{49}$ Právě tato hodnota nás vždy v minulosti činila tak silnými. Ochrana lidských práv včetně práv a důstojnosti cizinců tedy rozhodně neznamená, že jsme slabí a hloupí nebo neakceschopní.

JUDr. Kateřina Šimáčková, Ph.D.

Ústavní soud České republiky

katerina.simackova@usoud.cz

49 Čl. 1 naší Ústavy zdůrazňuje úctu k lidským právům a čl. 1 Listiny základních práv a svobod svobodu, rovnost a důstojnost každého člověka. 